\title{
Development of Survival Responsiveness to Brain-Derived Neurotrophic Factor, Neurotrophin 3 and Neurotrophin 4/5, But Not to Nerve Growth Factor, in Cultured Motoneurons from Chick Embryo Spinal Cord
}

\author{
Elena Becker, ${ }^{2}$ Rosa M. Soler, ${ }^{1}$ Víctor J. Yuste, ${ }^{1}$ Eva Giné, ${ }^{1}$ César Sanz-Rodríguez, ${ }^{1}$ Joaquim Egea, ${ }^{1}$ \\ Dionisio Martín-Zanca, ${ }^{2}$ and Joan X. Comella ${ }^{1}$ \\ ${ }^{1}$ Grup de Neurobiologia Molecular, Departament de Ciències Mèdiques Bàsiques, Facultat de Medicina, Universitat de \\ Lleida, 25198 Lleida, Catalonia, Spain, and IInstituto de Microbiología Bioquímica, Departamento de Microbiología y \\ Genética, Consejo Superior de Investigaciones Científicas-Universidad de Salamanca, 37007 Salamanca, Spain
}

During embryonic development, most neuronal populations undergo a process usually referred to as naturally occurring neuronal death. For motoneurons (MTNs) of the lumbar spinal cord of chick embryos, this process takes place in a well defined period of time, between embryonic days 6 and 10 (E6-E10). Neurotrophins (NTs) are the best characterized family of neurotrophic factors and exert their effects through activation of their specific Trk receptors. In vitro and in vivo studies have demonstrated that rodent motoneurons survive in response to BDNF, NT3, and NT4/5. In contrast, the trophic dependencies of chicken motoneurons have been difficult to elucidate, and various apparently conflicting reports have been published. In the present study, we describe how freshly isolated motoneurons from E5.5 chick embryos did not respond to any neurotrophin in vitro. Yet, because motoneurons were maintained alive in cul- ture in the presence of muscle extract, they developed a delayed specific survival response to BDNF, NT3, and NT4/5 that is clearly dose-dependent, reaching saturation at doses of 100 $\mathrm{pg} / \mathrm{ml}$. This trophic response correlated with increasing expression of the corresponding functional receptors TrkB and TrkC. Moreover, TrkB receptor is able to become autophosphorylated and to activate classical intracellular signaling pathways such as the extracellular signal-regulated protein kinase when it is stimulated with its cognate ligand BDNF. Therefore, our results reconcile the reported differences between in vivo and in vitro studies on the ability of chicken MTNs to respond to some members of the neurotrophin family of trophic factors.

Key words: neurotrophin; motoneuron; apoptosis; neurotrophism; TrkB; TrkC nervous system; chicken
Neurotrophins (NTs), which include NGF, BDNF, NT3, and $\mathrm{NT} 4 / 5$, are by far the best-characterized family of neurotrophic factors (Lewin and Barde, 1996). Each of these NTs exhibits trophic effects on a specific, although partially overlapping, subset of CNS or PNS neuronal populations both in vivo and in vitro (Barde et al., 1982; Davies, 1994a,b, 1996). NTs show binding to two types of receptors: p $75^{\text {LNTR }}$ and the Trk family of tyrosine kinases. All NTs bind to the p75; however, they show a high degree of specificity for the Trks. TrkA is the preferential receptor for NGF, TrkB is the preferred receptor for BDNF and NT4/5, and TrkC is the primary receptor for NT3 (Barbacid, 1995; Chao and Hempstead, 1995).

Several apparently contradictory results have been reported regarding the trophic dependencies of spinal cord motoneurons

\footnotetext{
Received Jan. 29, 1998; revised June 26, 1998; accepted July 13, 1998.

This work was funded by Comisión Interministerial de Ciencia y Tecnología SAF97-94 (J.X.C.) and Dirección General de Investigación Científica y Técnica PB94-1104 (D.M.-Z.), and European Union Programs BMH1-1471 (D.M.-Z.), BMH2-0010 (D.M.-Z., J.X.C.), and BIO4-433 (J.X.C.). We thank colleagues from both laboratories for critical reading of this manuscript. The contribution of $\mathrm{X}$. Dolcet in the final elaboration of this work is especially acknowledged. We are grateful to Xavier Calomarde for helping with photographic work and Dr. Joan Fibla for purification of NGF.

E.B. and R.M.S. contributed equally to the elaboration of the present work. D.M.-Z. and J.X.C. are senior co-authors.

Correspondence should be addressed to Joan X. Comella, Grup de Neurobiologia Molecular, Departament de Ciències Mèdiques Bàsiques, Universitat de Lleida, Rovira Roure 44, E-25198 Lleida, Spain.

Dr. Sanz-Rodríguez's present address: Servicio de Hematología, Hospital Universitario de la Princesa, 28006 Madrid, Spain.

Copyright (ㄷ) 1998 Society for Neuroscience $\quad 0270-6474 / 98 / 187903-09 \$ 05.00 / 0$
}

(MTNs). In rodents, BDNF and NT4/5 have been shown to promote the survival of axotomized immature MTNs (Vejsada et al., 1995), and in vitro studies have demonstrated that these neurons can respond to BDNF, NT3, and NT4/5 (Henderson et al., 1993; Hughes et al., 1993b). Interestingly, all three NTs are expressed in muscle tissue (Maisonpierre et al., 1990; Henderson et al., 1993; Koliatsos et al., 1993; Funakoshi et al., 1995), whereas their corresponding high-affinity receptors, TrkB and TrkC, are expressed in MTNs (Henderson et al., 1993; Koliatsos et al., 1993; Yan et al., 1993). Therefore, it seems that BDNF, NT3, and NT4/5 can contribute to maintaining alive rat MTNs. However, results reported for chicken MTNs are more difficult to interpret. Several laboratories have documented that cultured chick embryo MTNs do not respond to any NT (Arakawa et al., 1990; BlochGallego et al., 1991). Yet, daily injections of BDNF in the chorioallantoid membrane of chick embryos were able to rescue a fraction of the MTNs that would normally die between embryonic day 6 (E6) and E10 (Oppenheim et al., 1992, 1993). NT4/5 has also been reported to be active on chick MTN during embryonic cell death (Oppenheim et al., 1993), a result contrary to what has been described for some populations of chick sensory neurons (Davies et al., 1993).

In the present report, we describe how freshly isolated MTNs from E5.5 chick embryos did not respond to any NT. Yet, if MTNs were maintained alive in culture in the presence of muscle extract, they developed a delayed specific survival response to BDNF, NT3, and NT4/5. Moreover, the appearance of the tro- 
phic response to these NTs correlated with increasing expression of the corresponding functional high-affinity receptors TrkB and TrkC. The biological effects of BDNF and NT4/5 were mediated by TrkB, whereas those of NT3 were dependent on TrkC activation, as suggested by the stimulation of receptor tyrosine phosphorylation observed during NT treatment. It is concluded that cultured chicken MTNs are able to show a survival response to several NTs, as do their corresponding rodent counterparts.

\section{MATERIALS AND METHODS}

Isolation and culture of MTNs. MTNs were purified from chick embryos according to Comella et al. (1994). Briefly, whole spinal cords were dissected from E5.5 Arbor Acres chick embryos (COPAGA, Lleida, Spain), rinsed in GHEBS dissection buffer ( $137 \mathrm{~mm} \mathrm{NaCl}, 2.7 \mathrm{~mm} \mathrm{KCl}$, $22.2 \mathrm{~mm}$ glucose, $25 \mathrm{~mm}$ HEPES buffer, $\mathrm{pH}$ 7.4, $20 \mathrm{IU} / \mathrm{ml}$ penicillin, 20 $\mu \mathrm{g} / \mathrm{ml}$ streptomycin). Typically, 16 spinal cords were dissected per experiment, every four spinal cords being processed independently in conic tubes. They were first incubated with $0.05 \%$ trypsin (Sigma, St. Louis, $\mathrm{MO}$ ) in GHEBS buffer for $15 \mathrm{~min}$ at $37^{\circ} \mathrm{C}$. Next, once trypsin was removed, spinal cords were dissociated by pipetting through a Gilson blue pipette tip in complete Leibovitz's 15 culture medium (L15) (Sigma) supplemented with $18 \mathrm{~mm}$ glucose, $22.5 \mathrm{~mm}$ bicarbonate, $2.5 \mathrm{~mm}$ glutamine, $20 \mathrm{UI} / \mathrm{ml}$ penicillin, $20 \mu \mathrm{g} / \mathrm{ml}$ streptomycin, $10 \%$ heatinactivated horse serum (L15H) (Life Technologies, Renfrewshire, Scotland, UK), $2 \mathrm{~mm}$ pyruvic acid, and $0.02 \%(\mathrm{w} / \mathrm{v})$ DNase I (Boehringer Mannheim, Mannheim, Germany). The single cell suspension thus obtained was next layered onto $5 \mathrm{ml}$ of complete L15 medium lacking horse serum and containing 3.5\% (w/v) BSA (Sigma) and then spun at $100 \times$ $g$ for $5 \mathrm{~min}$ to remove cell debris. Pelleted cells were resuspended in $1 \mathrm{ml}$ of GHEBS buffer supplemented with $2 \mathrm{~mm}$ pyruvic acid, $0.02 \%$ DNase I, and $0.245 \%(\mathrm{w} / \mathrm{v}) \mathrm{BSA}$. The resulting cell suspension was layered onto 4 $\mathrm{ml}$ of $28 \%$ (v/v) Nycodenz [ $5^{\prime}-\left(N-2^{\prime}, 3^{\prime}\right.$-dihydroxypropylacetamido)-2', 4', $6^{\prime}$-triiodo- $N$, $N^{\prime}$-bis $\left(2^{\prime}, 3^{\prime}\right.$ - dihydroxypropyl)-isophthalamide), supplied as an isotonic sterile solution with a density of $1.15 \mathrm{gm} / \mathrm{ml}$ ) (Nycomed AS, Oslo, Norway) in GHEBS buffer and centrifuged at $400 \times g$ for 10 min. Last, the intermediate layer was collected and transferred into an appropriate amount of $\mathrm{L} 15 \mathrm{H}$ containing $2 \mathrm{~mm}$ pyruvate. MTNs were plated in 96-well or $60 \mathrm{~mm}$ culture dishes (Corning, New York, NY) precoated with poly-DL-ornithine $(30 \mu \mathrm{g} / \mathrm{ml}$ for $30 \mathrm{~min})$ (Sigma) and laminin $(2 \mu \mathrm{g} / \mathrm{ml}$ for $1 \mathrm{hr})$ (Life Technologies) at a density of 15,000 MTNs/well or 2-3 $\times 10^{6} \mathrm{MTNs} / 60 \mathrm{~mm}$ culture dish, respectively. Cultures were maintained at $37^{\circ} \mathrm{C}$ in a saturating humidity atmosphere of $95 \%$ air, $5 \% \mathrm{CO}_{2}$.

Evaluation of neuronal survival. Unless indicated otherwise, cells were cultured in 96-well plates in the presence of denervated muscle extract (MEX) added at a final concentration of $300 \mu \mathrm{g} / \mathrm{ml}$ (Comella et al., 1994). At different times, cells were washed with L15H, and culture medium was replaced with $50 \mu \mathrm{l}$ of fresh medium containing the trophic factor to be tested. The number of cells was determined in the central area of every well using a phase-contrast inverted microscope at $20 \times$ magnification. Only those cells with neurites longer than two cell diameters were counted. That value represented our corrected $100 \%$ survival. Counts were performed every $24 \mathrm{hr}$ in the same microscopic field throughout the duration of the experiment, and survival was expressed as a percentage of neuronal counts with respect to the initial $100 \%$ value. Values shown are the mean \pm SEM of these percentages and represent the average of eight wells. Each experiment was repeated at least three times.

Culture of PC12 cells. PC12 cells were grown in $100 \mathrm{~mm}$ culture dishes (Corning) in DMEM (Sigma) supplemented with 6\% heat-inactivated horse serum (Life Technologies) and $6 \%$ heat-inactivated fetal calf serum (Life Technologies) containing $10 \mathrm{~mm}$ HEPES and $20 \mathrm{IU} / \mathrm{ml}$ penicillin plus $20 \mu \mathrm{g} / \mathrm{ml}$ streptomycin. Cells were maintained at $37^{\circ} \mathrm{C}$ in a saturating humidity atmosphere of $95 \%$ air, $5 \% \mathrm{CO}_{2}$ and subcultured every 3-4 d. For experiments, cells were plated at $70 \%$ confluence and grown for $1 \mathrm{~d}$ in $60 \mathrm{~mm}$ culture dishes.

Western blot analysis. Tyrosine autophosphorylation of Trks, during binding of the specific human recombinant NTs (Alomone Laboratories, Jerusalem, Israel) or after MEX stimulation was monitored by immunoblotting with the anti-phosphotyrosine monoclonal antibody 4G10 (kindly provided by Dr. David Kaplan, Montreal Neurological Institute, Montreal, Canada, or obtained from UBI, Lake Placid, NY). Briefly, MTNs isolated by the Nycodenz-gradient technique were plated on a substrate of poly-DL-ornithine/laminin in $60 \mathrm{~mm}$ tissue culture dishes and main- tained in the presence of MEX and, in some experiments, in the presence of glial-derived neurotrophic factor (GDNF) (kindly provided by Eugene Johnson, St. Louis MO) or ciliary neurotrophic factor (CNTF) (Alomone Laboratories, Jerusalem, Israel) plus basic fibroblast growth factor (bFGF) (Boehringer Mannheim). At appropriate times, cells were rinsed thrice with L15H and maintained for $2 \mathrm{hr}$ in the absence of MEX before fresh medium containing the appropriate NT or MEX was added. PC12 cells were allowed to proliferate in $60 \mathrm{~mm}$ tissue culture dishes until they reached $80 \%$ confluence. Medium containing MEX or NTs was added to cultures for $5 \mathrm{~min}$ at $37^{\circ} \mathrm{C}$. At the end of the treatment, cultures were rinsed rapidly in ice-cold PBS $\left(4.3 \mathrm{mM}, \mathrm{Na}_{2} \mathrm{HPO}_{4^{-}}-7 \mathrm{H}_{2} \mathrm{O}\right.$, $\left.1.4 \mathrm{mM} \mathrm{KH}_{2} \mathrm{PO}_{4}, \mathrm{pH} 7.2,137 \mathrm{~mm} \mathrm{NaCl}, 2.7 \mathrm{~mm} \mathrm{KCl}\right)$ and lysed at $4^{\circ} \mathrm{C}$ in $0.5 \mathrm{ml}$ of Tris/NP-40 lysis buffer (20 mM Tris, $\mathrm{pH} 7.4,150 \mathrm{~mm} \mathrm{NaCl}$, 2 mM EDTA, 1 mM EGTA, $1 \%$ NP-40, 0.4 mM sodium orthovanadate, 1 mM phenylmethylsulfonylfluoride, $10 \mu \mathrm{g} / \mathrm{ml}$ aprotinin, $2 \mathrm{~mm}$ benzamide, and $20 \mu \mathrm{g} / \mathrm{ml}$ leupeptin). After a $15 \mathrm{~min}$ incubation on ice, the samples were spun in a microcentrifuge for $15 \mathrm{~min}$ at $4^{\circ} \mathrm{C}$ to remove nuclei and cellular debris. To determine the level of TrkA, TrkB, or TrkC tyrosine phosphorylation, lysates $(\sim 200 \mu \mathrm{g}$ of total protein per lane) were immunoprecipitated for $1 \mathrm{hr}$ at $4^{\circ} \mathrm{C}$ with a pan-Trk polyclonal antibody (anti203) raised against a 15 amino acid synthetic peptide corresponding to the $C$ terminus of human TrkA (sequence: QALAQAPPVYLDVLG) (Martín-Zanca et al., 1989). This antibody is known to immunoprecipitate TrkA, TrkB, and TrkC indistinctly. The resulting immunocomplexes were collected for $1 \mathrm{hr}$ at $4^{\circ} \mathrm{C}$ with protein A-Sepharose beads (Sigma), resolved in $7.5 \%$ SDS-PAGE gels, and transferred onto polyvinylidene difluoride (PVDF) membrane filters (Millipore, Bradford, MA). Membranes were blocked with TBS-T20 (20 mM Tris-HCl, pH 7.4, $150 \mathrm{~mm}$ $\mathrm{NaCl}, 0.05 \%$ Tween-20) containing $5 \%$ BSA for $1 \mathrm{hr}$ at room temperature, followed by incubation with the 4G10 anti-phosphotyrosine monoclonal antibody for $1 \mathrm{hr}$ at room temperature. After three washes with TBS-T20, membranes were incubated with anti-mouse IgG antibodyperoxydase conjugate (Sigma) for $1 \mathrm{hr}$ at room temperature. Last, blots were rinsed thrice with TBS-T20 and once with TBS. Reactive bands were detected with the ECL chemoluminescence system (Amersham, Buckinghamshire, UK). To determine tyrosine phosphorylation of proteins in total cell lysates, $25 \mu \mathrm{g}$ of protein was electrophoresed in $10 \%$ SDS-PAGE gels, transferred onto PVDF membrane filters, and immunodetected with $4 \mathrm{G} 10$ monoclonal antibody as described. Filters were then stripped with $100 \mathrm{~mm} \beta$-mercaptoethanol, $2 \%$ SDS in $62.5 \mathrm{~mm}$ Tris- $\mathrm{HCl}$, pH 6.7 , for $30 \mathrm{~min}$ at $50^{\circ} \mathrm{C}$. Blots were rinsed with TBS for 10 min twice and processed for the immunodetection of extracellular signalregulated protein kinase (ERK) proteins by using a mouse monoclonal pan-ERK antibody (Transduction Laboratories, Lexington, KY) following the same protocol described for the anti-phosphotyrosine antibody.

ERK2 immunoprecipitation was performed using a specific anti-ERK2 polyclonal antibody (Transduction Laboratories, Lexington, KY) overnight at $4^{\circ} \mathrm{C}$. The immunocomplexes were electrophoresed in SDS-PAGE and transferred to PVDF membranes as described. Detection of phosphotyrosine-containing proteins was assessed with the $4 \mathrm{G} 10$ antibody, and reprobing of membranes with the anti-pan-ERK antibody was performed as described above.

$R N A$ extraction. Total cellular RNA was extracted, following the acid-guanidium-thiocyanate-phenol-chloroform procedure of Chomczynski and Sacchi (1987), from chick embryo MTNs that had been in culture, in the presence of MEX, for 24,72 , or $96 \mathrm{hr}$.

Preparation of riboprobes. Radiolabeled antisense RNA probes were synthesized from appropriate plasmid templates, as follows: the trkB riboprobe was prepared from pEB20, a pGEM-T based plasmid that contains a 405-bp-long cDNA insert corresponding to nucleotides 1798 2203 of chicken trkB (Dechant et al., 1993). BglII linearized pEB20 was transcribed with SP6 RNA polymerase (Stratagene, La Jolla, CA) to yield a 294 nucleotide RNA probe, with 223 bases complementary to the full length $\operatorname{trkB}$ transcript. The $\operatorname{trk} C$ riboprobe was synthesized from pEB21, a pGEM-T-derived plasmid containing a 604 bp cDNA insert corresponding to nucleotides $1984-2588$ of the chicken cDNA with a 75 bp alternative exon (trkC75i) (Garner and Large, 1994). This plasmid was linearized with Bsu36I and transcribed using T7 RNA polymerase (Stratagene) to generate a 421-nucleotides-long RNA probe, 406 of which are complementary to the trkC transcript containing the 75 bp insert, whereas two segments of 249 and 82 nucleotides are complementary to the $t r k C$ transcript lacking the insert. The chicken $\beta$-actin riboprobe was synthesized from pEB13.1, a BluescriptKS-based plasmid that contains a HindIII-NcoI 105-bp-long cDNA insert corresponding to the $5^{\prime}$ end of the chicken $\beta$-actin clone (Cleveland et al., 1978). HindIII-linearized 
pER13.1 was transcribed with T7 RNA polymerase (Stratagene, La Jolla, CA, USA) into a 160-nucleotides-long RNA probe, 86 of which are complementary to the $\beta$-actin transcript. Riboprobes were synthesized at $37^{\circ} \mathrm{C}$ for $1 \mathrm{hr}$, using $200 \mathrm{ng}$ of template and $50 \mu \mathrm{Ci}\left[{ }^{32} \mathrm{P}\right] \mathrm{UTP}(800$ $\mathrm{Ci} / \mathrm{mmol}$ ) (Amersham), in the presence of $20 \mathrm{U}$ RNAsin (Promega, Madison, WI). After transcription, the DNA template was removed by using $1 \mathrm{U}$ RNase-free DNase (Promega) and incubating for $30 \mathrm{~min}$ at $37^{\circ} \mathrm{C}$, followed by phenol-chloroform extraction and ethanol precipitation. Probes were resuspended in gel loading buffer, resolved on a $6 \%$ denaturating acrylamide gel containing $8 \mathrm{M}$ urea, and eluted at $37^{\circ} \mathrm{C}$ in $500 \mathrm{~mm}$ ammonium acetate, $10 \mathrm{~mm}$ magnesium acetate, $1 \mathrm{~mm}$ EDTA, and $0.1 \%$ SDS.

$R$ Nase protection assays. Total RNA samples ( $6 \mu \mathrm{g}$ per condition) were combined with $5 \times 10^{5} \mathrm{cpm}$ of either the trkB or trkC probes, together with $5 \times 10^{4} \mathrm{cpm}$ of the $\beta$-actin probe in $25 \mu$ l hybridization buffer containing $80 \%$ formamide, $40 \mathrm{~mm}$ PIPES, $\mathrm{pH} 6.4,400 \mathrm{~mm}$ sodium acetate, $1 \mathrm{~mm}$ EDTA. Samples were mixed, placed in a water bath at $85^{\circ} \mathrm{C}$ for $5 \mathrm{~min}$, then transferred to a $50^{\circ} \mathrm{C}$ water bath and incubated for 13-16 hr. After hybridization, $200 \mu \mathrm{l}$ of RNase digestion buffer $(10 \mathrm{~mm}$ Tris- $\mathrm{HCl}, \mathrm{pH} 8.0,375 \mathrm{~mm} \mathrm{NaCl}, 5 \mathrm{~mm}$ EDTA) containing $1 \mu \mathrm{l}$ of a mixture of $750 \mathrm{U} / \mathrm{ml}$ RNase A and 20,000 U/ml RNase T1 (Ambion, Austin, TX) was added; samples were incubated at $28^{\circ} \mathrm{C}$ for $1 \mathrm{hr}$ followed by a further incubation at $37^{\circ} \mathrm{C}$ for $20 \mathrm{~min}$ in the presence of $0.75 \%$ SDS and $200 \mu \mathrm{g} / \mathrm{ml}$ proteinase K. After phenol-chloroform extraction, samples were ethanol-precipitated and analyzed on a $6 \%$ acrylamide denaturating gel containing $8 \mathrm{M}$ urea. Dried gels were exposed to x-ray at $-80^{\circ} \mathrm{C}$. Quantitative analysis was performed on a Fuji film BAS 1500 phosphoroimager using MacBas v2.5 software.

\section{RESULTS}

\section{Chick embryo MTNs survive in the presence of MEX}

MTNs were isolated from E5.5 chick embryo spinal cords essentially as described by Comella et al. (1994). This technique allows the purification of MTNs from a total cellular dissociate from the spinal cord by centrifugation through a Nycodenz density gradient. This procedure takes advantage of the fact that MTNs are the most buoyant cells in the spinal cord at this developmental stage, and it yields a pure $(>90 \%)$ population of MTNs according to morphological and biochemical criteria (Comella et al., 1994; Mettling et al., 1995). Isolated MTNs were cultured in poly-DLornithine/laminin-coated 96-well culture dishes. Neurons were initially seeded in $\mathrm{L} 15 \mathrm{H}$ medium. After $1 \mathrm{hr}$ in culture, plating medium was replaced with fresh $\mathrm{L} 15 \mathrm{H}$ medium supplemented with $300 \mu \mathrm{g} / \mathrm{ml}$ of MEX. The presence of MEX in the culture medium is absolutely necessary to maintain this population of neurons alive (Comella et al., 1994). Thus, when MTN cultures were deprived of MEX, $<5 \%$ of the cells initially seeded remained alive $36 \mathrm{hr}$ later (data not shown). MTNs cultured in the presence of MEX developed prominent neurite outgrowth and showed positive staining with anti-neurofilament and anticholineacetyltransferase antibodies (data not shown), thus demonstrating the neuronal and cholinergic nature of these cells, respectively (Comella et al., 1994).

\section{Development of survival responsiveness of MTNs to BDNF, NT3, and NT4/5}

Several laboratories have reported that freshly isolated chick embryo spinal cord MTNs do not show survival responses to any of the different NTs in vitro (Dohrmann et al., 1986; Arakawa et al., 1990; Berkemeier et al., 1991; Bloch-Gallego et al., 1991; Thoenen, 1991). Our results are in agreement with those reported previously. Freshly plated chick embryo MTNs did not exhibit any survival response to the NTs tested, i.e., NGF, BDNF, NT3, or NT4/5. Indeed, the survival response observed in the presence of the different NTs was comparable to that obtained using basal culture medium. This was in clear contrast to the survival response observed in those MTN cultures exposed to saturating

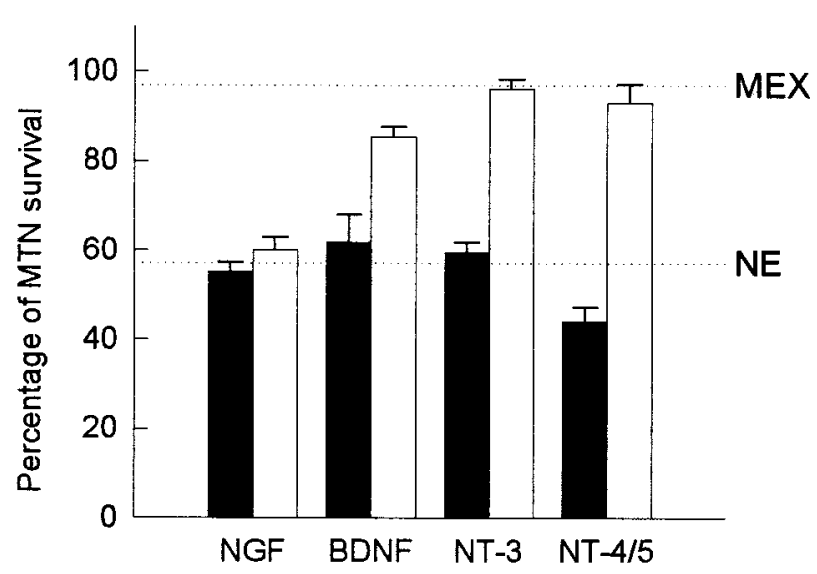

Figure 1. The survival response of MTNs to NTs varies with time in culture. MTNs were purified from E5.5 chick embryos and cultured in the presence of MEX $(300 \mu \mathrm{g} / \mathrm{ml}$ ) for $24 \mathrm{hr}$ (black bars) or $72 \mathrm{hr}$ (white bars), whereupon cultures were rinsed three times with basal medium and cultured for an additional $24 \mathrm{hr}$ period in the presence of MEX (300 $\mu \mathrm{g} / \mathrm{ml}$ ) or with $50 \mathrm{ng} / \mathrm{ml}$ of the different NTs. The number of MTNs in the central part of the culture well was determined by counting them with an inverted microscope at times when culture media were changed and at the end of the $24 \mathrm{hr}$ NT test period. The bars show the percentage of surviving MTNs under the different culture conditions at the end of the experiment. The conditions represented are cells exposed to nerve growth factor $(N G F)$, to brain-derived neurotrophic factor $(B D N F)$, to neurotrophin $3(N T-3)$, or to neurotrophin 4/5 (NT-4/5). Each bar represents the mean \pm SEM of eight wells from a single experiment that was repeated twice more with results comparable to those presented. The horizontal dotted lines indicate the level of MTN survival, at the end of the $24 \mathrm{hr}$ period, in the presence (top line, $M E X$ ) or absence (bottom line, $N E$ ) of MEX.

concentrations (300 $\mu \mathrm{g} / \mathrm{ml})$ of MEX. Interestingly, we detected a significant shift in the ability of cultured MTNs to respond to the different NTs, because neurons were maintained in culture for longer periods of time (Fig. 1). When MTNs that had been cultured for $24 \mathrm{hr}$ in the presence of MEX and thereafter were exposed to the different NTs while in the absence of MEX, no survival-promoting effect was observed with any of the NTs tested, i.e., NGF, BDNF, NT3, or NT4/5 (Fig. 1). However, in 48 hr MTN cultures, BDNF and NT4/5 exhibited a moderate survival-promoting effect (data not shown), which became very evident after $72 \mathrm{hr}$ in culture (Figs. 1, 2). Moreover, NT3 also behaved as a potent stimulator of MTN survival in $72 \mathrm{hr}$ cultures. No survival response for NGF was observed at any of the culture times tested (Fig. 1). It should be noted that in $72 \mathrm{hr}$ MTN cultures, the three NTs-BDNF, NT3, and NT4/5-promoted MTN survival in a clear dose-dependent manner (Fig. 2). Thus, BDNF, NT3, and NT4 are able to induce the MTN survival at very low doses, being saturating at $100 \mathrm{pg} / \mathrm{ml}$. These results suggest that NTs are acting through their corresponding highaffinity receptors to induce the MTN survival response. NGF addition to MTN cultures did not show any significant survival induction, although very high doses were used (up to $50 \mathrm{ng} / \mathrm{ml}$ ).

The fact that no response to the different NTs could be observed in MTNs shortly after being isolated from E6 chick embryos, i.e., at the beginning of the period of cell death for MTNs of the lumbar spinal cord, suggested that NTs are not responsible for the trophic activity present in MEX, which is able to suppress the death of embryonic MTNs at this age in vitro (Fig. 1) (Comella et al., 1994). 

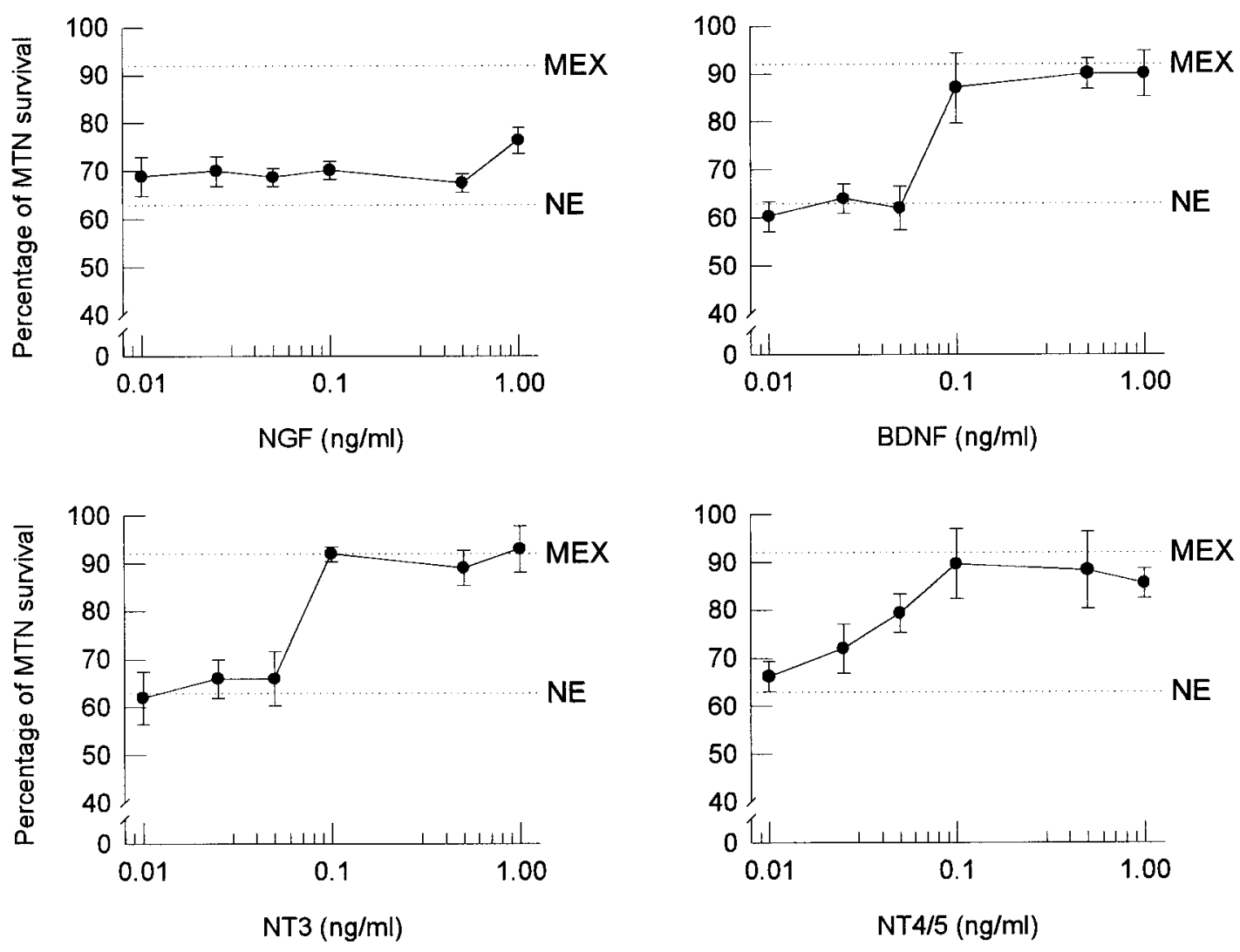

Figure 2. BDNF, NT3, and NT4/5 exert their neurotrophic effect on cultured MTNs in a dose-dependent manner. MTNs were purified from E5.5 chick embryos and cultured in the presence of $\operatorname{MEX}(300 \mu \mathrm{g} / \mathrm{ml})$ for $72 \mathrm{hr}$, whereupon cultures were rinsed thrice with basal medium and cultured for an additional $24 \mathrm{hr}$ period in the presence of varying concentrations of the different NTs. The number of MTNs in a defined area of the culture well was determined at times when culture media were changed and at the end of the $24 \mathrm{hr}$ NT test period. The points show the percentage of surviving MTNs at the end of the experiment. Dotted lines indicate the level of MTN survival in the presence (top line, MEX) or absence (bottom line, NE) of MEX. Each bar represents the mean \pm SEM of eight wells from a representative experiment that was repeated twice more with results comparable to those presented.

\section{Expression of mRNA for trkB and trkC in MTNs increases with time in culture}

The results reported above showed that MTNs that had been cultured for $72 \mathrm{hr}$ in the presence of MEX developed the ability to respond to low doses of BDNF, NT3, and NT4/5 during the culture time (Figs. 1, 2), suggesting a correlation with the expression of TrkB and TrkC receptors. To test this hypothesis we analyzed the expression of messenger RNAs for $\operatorname{trk} B$ and $t r k C$ in cultured MTNs using a sensitive RNase protection assay. For these experiments, total RNAs extracted from MTNs that had been in culture for 24,72 , and 96 hr were hybridized with labeled antisense riboprobes corresponding to the kinase domains of either $\operatorname{trk} B$ or $\operatorname{trk} C$, together with a $\beta$-actin RNA probe used as an internal control to allow for quantitative analysis (see Materials and Methods).

Specific protection of the expected 223 nucleotide trkB RNA fragment was detected in MTNs cultured for $24 \mathrm{hr}$ in the presence of MEX, indicating expression of the $\operatorname{trkB}$ gene under this conditions. Normalized trkB mRNA levels increased 2.5-fold after $72 \mathrm{hr}$ in culture and remained stable after $96 \mathrm{hr}$ (Fig. 3, left). In addition to that fragment, protection of an extra one of 211 was consistently observed, both in MTNs (Fig. 3, left) and in chicken brain RNA (data not shown). This may represent the expression of an alternative $\operatorname{trk} B$ transcript that has not been characterized to date.

The trk $C$ riboprobe used in these experiments allowed us to monitor the expression of different trk $C$ isoforms; thus, expression of the full length transcript resulted in specific protection of a 249-nucleotide fragment, whereas expression of the isoform with a kinase insert should yield a 406-nucleotide fragment. In cultured MTNs we have been able to detect the expression of only the full length transcript, which is already present at the $24 \mathrm{hr}$ culture time. Normalized trkC mRNA levels increased twofold after $72 \mathrm{hr}$ in culture, decreasing slightly $24 \mathrm{hr}$ later (Fig. 3, right). These results seem to indicate that cultured MTNs express only the TrkC isoforms lacking kinase inserts; however, RT-PCR experiments allowed us to detect the expression of a transcript containing the 75-nucleotide insert in these cultures (data not shown).

\section{BDNF, NT3, and NT4/5 stimulate the autophosphorylation of their cognate high-affinity receptors, TrkB and TrkC, in cultured MTNs}

BDNF, NT3, and NT4/5 were all active on MTNs at doses (near $1 \mathrm{~nm}$ ) compatible with the stimulation of their respective highaffinity receptors, i.e., TrkB for BDNF and NT4/5, and TrkC for NT3 (Fig. 2). In agreement with these results, it has been reported previously that mice MTNs express mRNAs for TrkB and TrkC (Henderson et al., 1993; Koliatsos et al., 1993; Yan et al., 1993). Nevertheless, direct detection of TrkB and TrkC proteins has been difficult in primary neuronal cultures. In this study, we were able to detect Trk proteins in cultured MTNs by following 


\section{Time in culture (hours)}

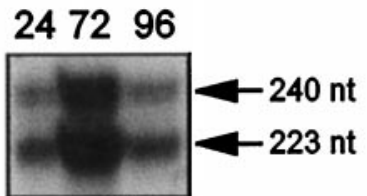

TK TrkB
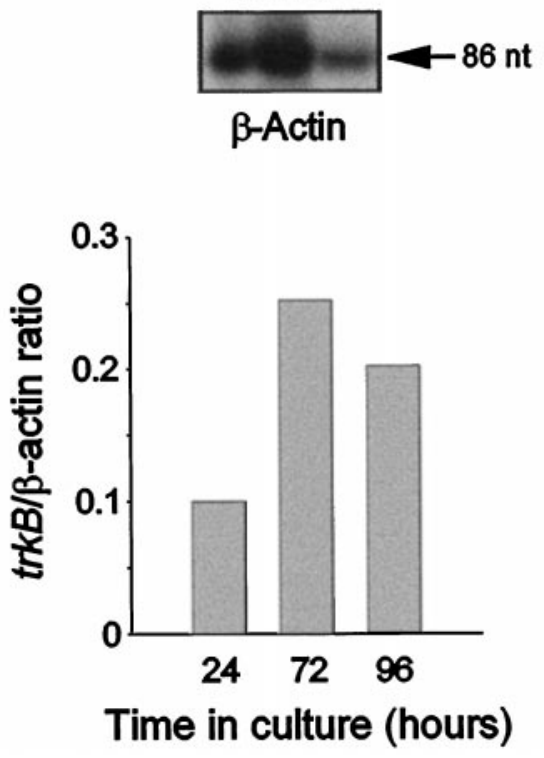

247296

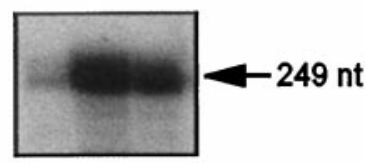

TK TrkC75i

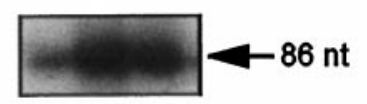

$\beta$-Actin

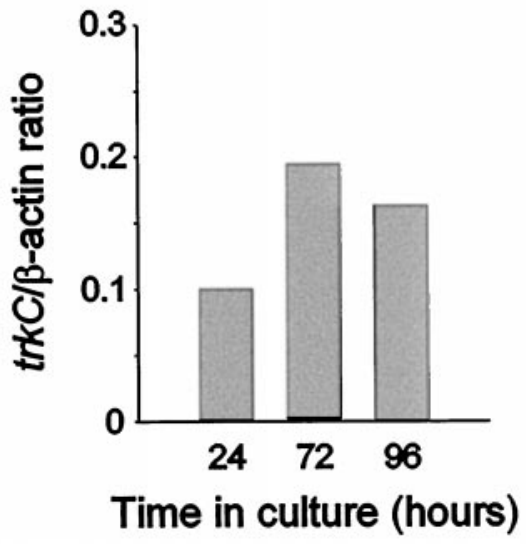

Figure 3. TrkB and TrkC mRNA levels increase with time in culture. RNase protection analysis of total RNA ( $6 \mu \mathrm{g}$ per sample) from MTNs cultured in the presence of MEX for 24, 72, and $96 \mathrm{hr}$, using labeled riboprobes corresponding to the tyrosine kinase domains of chicken $\operatorname{trk} B$ (left) or $t r k C$ with a $75 \mathrm{bp}$ insert (right). As an internal control, a chicken $\beta$-actin riboprobe was included in all samples. Arrows indicate the migration and sizes of the specific protected fragments. Left, Protection of a 223-nucleotide-long fragment from the trkB probe indicates expression of full-length trkB; the 211-nucleotide-long protected fragment may reflect the expression of a different trkB isoform, which has not been characterized to date. Right, Protection of a 249nucleotide-long fragment from the trkC75i probe indicates expression of the full-length trkC isoform lacking a kinase insert. $\beta$-actin expression results in the protection of an 86nucleotide-long fragment. Bottom panels, The amount of radioactivity present in each protected fragment was quantified using a Fuji film BAS 1500 phosphoroimager, and the trkB and $t r k C$ levels were normalized against those of the $\beta$-actin control. a strategy based on the detection of tyrosine autophosphorylation of these receptors after treatment with specific NTs. Cell lysates obtained from chicken MTN cultures stimulated with the different NTs were immunoprecipitated using a polyclonal pan-Trk antibody (anti-203), which recognizes TrkA, TrkB, and TrkC indistinctly, followed by immunoblotting with the antiphosphotyrosine antibody 4G10. Although the anti-203 antibody does not discriminate between the different Trks, the experimental strategy described above allowed the selective identification of activated TrkA, TrkB, and TrkC, because tyrosine autophosphorylation of each of these receptors is specifically stimulated by binding to the corresponding preferred ligand when used at low nanomolar concentrations. For these experiments, MTNs were cultured in the presence of MEX for $72 \mathrm{hr}$, whereupon cells were acutely exposed to $50 \mathrm{ng} / \mathrm{ml}$ of the different NTs for $5 \mathrm{~min}$. As control, PC12 cells were stimulated with the same NTs.

Tyrosine phosphorylation analysis of Trk proteins revealed that both BDNF and NT3 were able to induce the autophosphorylation of a protein with a molecular weight compatible with that of Trk (140-145 kDa), thus suggesting the presence of TrkB and TrkC on the surface of MTNs. NGF, which induced the tyrosine phosphorylation of TrkA in PC12 cells, had no effect on MTNs (Fig. $4 A$ ). We then tested the possibility that MEX may contain significant amounts of NTs that could be responsible for its survival-inducing effect. MTN were cultured in the presence of MEX for $72 \mathrm{hr}$, whereupon cells were acutely exposed to different concentrations of MEX up to $1 \mathrm{mg} / \mathrm{ml}$ for $5 \mathrm{~min}$. Analysis of the corresponding cell lysates showed that none of the concentrations assayed were able to elicit Trk phosphorylation (Fig. 4B). Therefore, MEX does not seem to contain relevant levels of NTs.

\section{De novo synthesis of Trk receptors in cultured MTNs}

The lack of responsiveness of NTs observed in freshly isolated MTNs was probably caused by the absence of neurotrophin receptors on their surface at that time. To test this hypothesis, an experiment was performed in which MTNs that had been cultured in the presence of MEX for 24, 48, and $72 \mathrm{hr}$ were acutely exposed to $50 \mathrm{ng} / \mathrm{ml}$ of BDNF for $5 \mathrm{~min}$. Parallel cultures of MTNs, which had been maintained alive with MEX for $24 \mathrm{hr}$, were treated with cycloheximide $(0.5 \mu \mathrm{g} / \mathrm{ml})$ while in the presence of MEX for an additional $48 \mathrm{hr}$ period. At the end of that period, MTNs were also acutely exposed to BDNF. The rationale behind the use of a protein synthesis inhibitor was to determine whether the Trk protein detected in 3-d-old MTN cultures had been synthesized de novo. As shown in Figure $5 A$, the ability of BDNF to stimulate TrkB autophosphorylation in MTNs increased with time in culture. In 1-d-old MTN cultures it was not possible to detect any tyrosine phosphorylation of Trk proteins. However, in 2-d-old cultures a weak signal corresponding to tyrosine-phosphorylated TrkB was detected; this phosphorylation became much stronger in 3-d-old cultures (Fig. 5A). Cycloheximide treatment blocked the appearance of tyrosinephosphorylated TrkB in response to BDNF in 3-d-old MTN cultures (Fig. 5A), suggesting that as MTNs are maintained in culture in the presence of MEX, they synthesize Trk protein de novo. Overall, these results show a good correlation between the shift in the ability of cultured MTNs to respond to the different NTs (Fig. 1) and the temporal pattern of cell surface expression of Trk proteins in these cells (Fig. 5A).

Taken together, these experiments indicate that TrkB and TrkC are expressed at low levels by $24 \mathrm{hr}$ of MEX treatment, reaching maximal expression levels by $72 \mathrm{hr}$, but they do not undergo ligand-induced autophosphorylation or survival response until after $72 \mathrm{hr}$ of treatment with MEX. This may reflect a higher sensitivity of the RNase protection analysis as compared with the Western blot phosphotyrosine analysis. Alternatively, the translation of the mRNA or the protein transport to the cell 


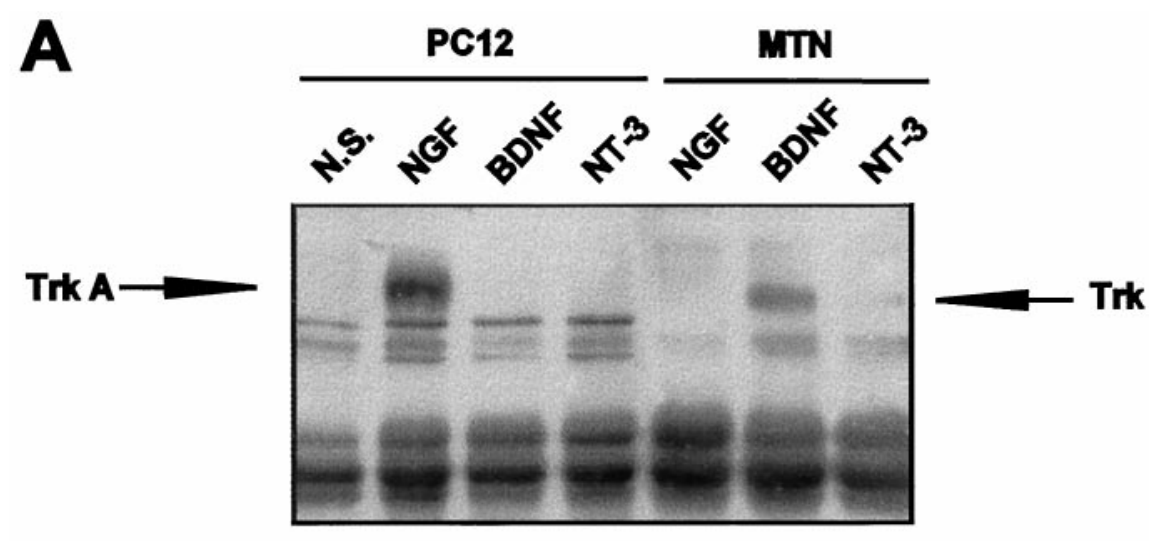

Figure 4. Chick embryo spinal cord MTNs express TrkB and TrkC receptors on their surface. $A$, MTN cultures were maintained in the presence of MEX (300 $\mu \mathrm{g} / \mathrm{ml}$ ) for $72 \mathrm{hr}$, whereupon cells were acutely exposed, during a period of $5 \mathrm{~min}$, to $50 \mathrm{ng} / \mathrm{ml}$ of NGF, BDNF, or NT3. Parallel PC12 cell cultures stimulated with the same NTs were used as controls. After this treatment, cells were lysed and immunoprecipitated with a pan-Trk antibody (anti-203). The resulting immunocomplexes were analyzed in $7.5 \%$ SDS-PAGE, blotted, and probed with the antiphosphotyrosine antibody 4G10. Arrows indicate the migration of the TrkA protein in PC12 cells and TrkB or TrkC in MTNs. N.S. indicates nonstimulated PC12 cells. $B$, MTN cultures were maintained in the presence of MEX $(300 \mu \mathrm{g} / \mathrm{ml})$ for $72 \mathrm{hr}$, whereupon cells were acutely exposed to the indicated concentrations of MEX and BDNF (50 ng/ml) or left untreated (N.S.). Tyrosine phosphorylation of the Trk receptor was analyzed as described in $A$. Trk $B$-labeled arrow indicates the migration of the TrkB protein.

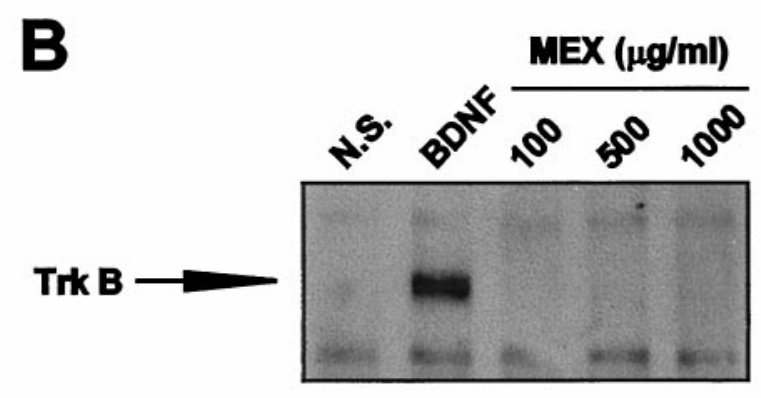

surface may be slow, resulting in a delayed accumulation of the Trk proteins at the plasma membrane, and may reach a detectable level only after 2-3 d in culture. In any case, it appears that the levels of $t r k B$ and $t r k C$ expression at earlier times are insufficient to elicit a survival response and that acquisition of NT responsiveness parallels the increased expression of both mRNAs and corresponding Trk proteins.

Another important question that has been examined is whether the ability of MEX to allow the appearance of Trk receptors on the MTN surface is an instructive or a permissive phenomenon. To examine this question, MTNs were cultured for $3 \mathrm{~d}$ in the presence of $300 \mu \mathrm{g} / \mathrm{ml}$ of MEX or, alternatively, in the presence of $100 \mathrm{ng} / \mathrm{ml}$ of GDNF or a combination of CNTF at $100 \mathrm{ng} / \mathrm{ml}$ plus bFGF at $100 \mathrm{ng} / \mathrm{ml}$. Then, cultures were acutely stimulated with BDNF as described for other experiments. Cell were lysed and submitted to Trk phosphorylation analysis. Figure $5 B$ shows that all the defined culture conditions tested allowed the appearance of functional TrkB receptors on the MTN surface, therefore suggesting that the role of $\mathrm{MEX}$ is more permissive than instructive.

\section{BDNF and NT3 stimulate tyrosine phosphorylation of ERK2 in cultured chicken MTNs}

Interestingly, the analysis of total cell lysates corresponding to 3-d-old MTN cultures revealed the appearance of several tyrosine-phosphorylated proteins after the activation of TrkB by BDNF and TrkC by NT3. Of particular interest was a single protein band with a molecular weight of $40-45 \mathrm{kDa}$ that showed increased tyrosine phosphorylation when MTNs were exposed to either BDNF (Fig. 4A) or NT3 (data not shown). The molecular weight of this protein suggested to us that it could be an ERK (Boulton et al., 1991). Reprobing the filters with a pan-ERK antibody showed that this phosphorylated protein co-migrates with the ERKs (Fig. 4B). To directly confirm that NTs stimulated the phosphorylation of ERK2, MTN lysates were immunoprecipitated with a specific anti-ERK2 antibody followed by Western blot analysis with the anti-phosphotyrosine 4G10 antibody. This experiment showed that treatment of MTNs with BDNF specifically stimulated the phosphorylation of the ERK2 protein on tyrosine residues (Fig. 4C). Reprobing the membranes containing the immunoprecipitates with a pan-ERK monoclonal antibody confirmed the identity of the phosphorylated protein as the kinase ERK2 (Fig. 4D).

\section{DISCUSSION}

During embryonic development, vertebrate organisms undergo a massive loss of neurons, which affects most neuronal populations. For MTNs of the lumbar spinal cord of the chick embryo, naturally occurring death occurs between E6 and E10 (Hamburger, 1975). Several members of the family of NTs, including BDNF, NT3, and NT4/5, have been shown to support the survival of rodent MTNs in vitro as well as to rescue MTNs from naturally occurring and axotomy-induced cell death in rats (Henderson, 1996; Oppenheim, 1996). However, in the last few years some apparently inconsistent reports have been published regarding the trophic dependencies of spinal cord MTNs from chick embryos. BDNF and NT4/5 were shown to block the ontogenetic death of MTNs in ovo (Oppenheim et al., 1992, 1993) but not in vitro (Arakawa et al., 1990; Bloch-Gallego et al., 1991). This discrepancy could indicate that in vivo NTs exert their biological effects on MTNs indirectly by acting on other cell types such as interneurons or glial cells. An alternative explanation is that some co-factors necessary for these NTs to promote the survival of MTNs in vivo may not be present in vitro. The results obtained in the present study suggest that chick embryo MTNs do not respond to NTs at the beginning of the ontogenetic cell death period but develop the ability to do so during the following days 


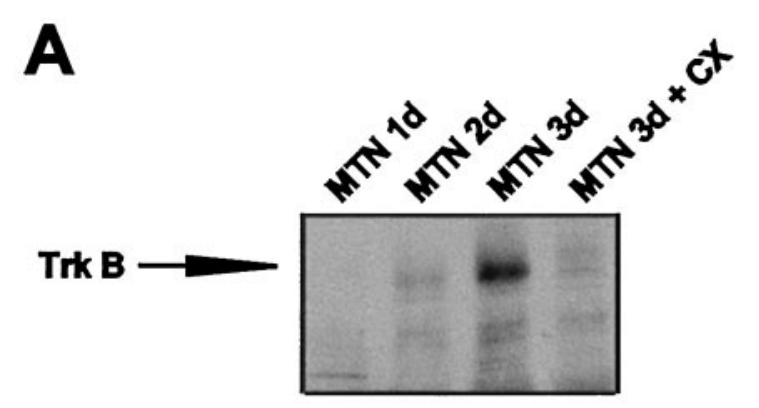

B

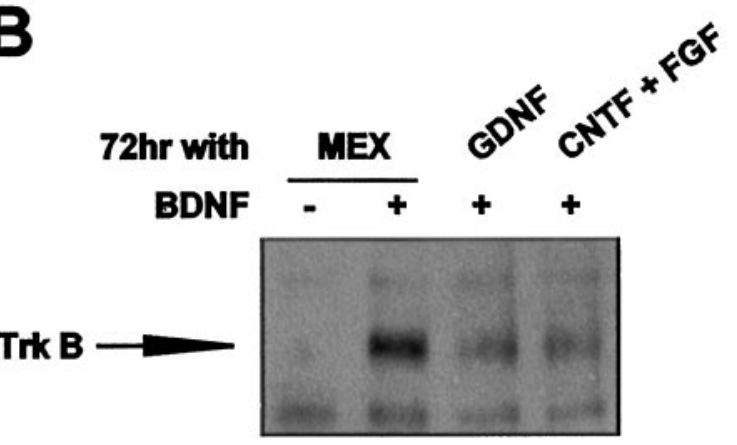

Figure 5. BDNF stimulation of TrkB phosphorylation in MTNs increases with time in culture. $A$, MTNs were maintained in the presence of $\operatorname{MEX}(300 \mu \mathrm{g} / \mathrm{ml})$ for 24,48 , and $72 \mathrm{hr}$, whereupon cells were acutely exposed to BDNF. Parallel cultures of MTNs, which had been maintained alive with MEX for $24 \mathrm{hr}$, were treated with cycloheximide $(0.5 \mu \mathrm{g} / \mathrm{ml})$ while in the presence of MEX for an additional $48 \mathrm{hr}$ period. At the end of that period, MTNs were also acutely exposed to BDNF. Thereafter, cells were lysed and immunoprecipitated with a pan-Trk antibody (anti203). The resulting immunocomplexes were analyzed by $7.5 \%$ SDSPAGE, blotted, and probed with the anti-phosphotyrosine antibody 4G10. $B$, MTNs were maintained in the presence of GDNF (100 ng $/ \mathrm{ml})$, CNTF $(100 \mathrm{ng} / \mathrm{ml})$ plus FGF $(100 \mathrm{ng} / \mathrm{ml})$, or $\operatorname{MEX}(300 \mu \mathrm{g} / \mathrm{ml})$ for $72 \mathrm{hr}$, whereupon cells were acutely exposed to BDNF $(+)$ or left untreated $(-)$. Tyrosine phosphorylation of the Trk receptors was analyzed as described in $A$. Trk B-labeled arrow indicates the migration of the TrkB protein.

of embryonic development. We found, in agreement with what other investigators have reported previously (Arakawa et al., 1990; Henderson et al., 1993), that freshly isolated chick embryo spinal cord MTNs did not show any survival response to the different members of the NT family in vitro. However, because MTNs were maintained in culture for longer periods of time (48-72 hr, which would be equivalent to E7-E8 in vivo), they became sensitive to the survival-promoting effect of BDNF, NT3, and NT4/5 (Figs. 1, 2). In the in vivo experiments in which BDNF and NT4/5 were found to rescue MTNs from naturally occurring cell death, neurotrophic agents were injected daily from E6 through E9 (Oppenheim et al., 1993). Thus, if MTNs developed the ability to respond to NTs at around E7-E8, as suggested by our present observations, BDNF and NT4/5 would still be able to rescue from death all those MTNs otherwise dying between then and E10. According to this hypothesis, experiments from the laboratory of Oppenheim (McKay et al., 1996) have shown that trkB mRNA was not present in chick embryo MTNs until after the process of physiological MTN death was underway around E8. These authors also demonstrated that daily injection of BDNF during the initial period of MTN cell death (E5-E7) was not able to increase the number of surviving MTNs, whereas embryos that were injected with BDNF during the later part of the process (E8-E11) showed a significant increase in the number
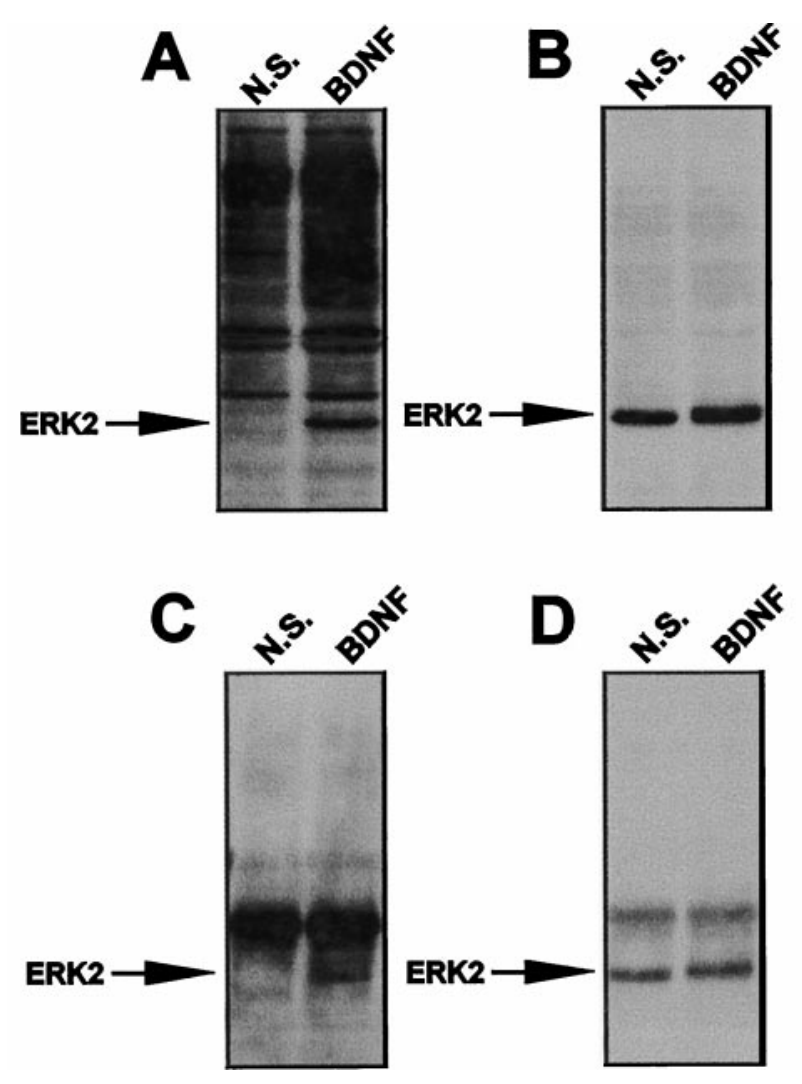

Figure 6. BDNF stimulates tyrosine phosphorylation of the ERK2 in MTNs. MTN cultures were maintained for $72 \mathrm{hr}$ in the presence of MEX $(300 \mu \mathrm{g} / \mathrm{ml})$, then were exposed to $50 \mathrm{ng} / \mathrm{ml}$ of BDNF for $5 \mathrm{~min}$ and lysed, and the cell lysates were analyzed by Western blot. $A$, Phosphorylation analysis of crude cell lysates $(25 \mu \mathrm{g}$ per lane) using the antiphosphotyrosine antibody 4G10. C, Tyrosine phosphorylation of ERK2. Cell lysates were immunoprecipitated with a specific anti-ERK2 polyclonal antibody, and the immunocomplexes were analyzed by Western blot with the 4G10 antibody. Membranes were stripped and reprobed with an anti-pan-ERK monoclonal antibody $(B, D)$. ERK2-labeled arrows indicate the migration of the ERK2 protein.

of MTNs. Therefore, it seems that there is a good correlation between these in vivo results and our in vitro experiments.

Temporal shift or transient response to neurotrophic factors in several defined populations of neurons has been reported (Davies, 1994b). For example, quail MTN show an accelerated differentiation in response to NT3 in early phases of their development but show no survival response to NT3 at the beginning of the period of physiological neuronal death (Averbuch-Heller et al., 1994). Similarly, Mettling et al. (1995) reported a transient period of neurotrophic-independent survival in chicken MTNs. Therefore, the results presented here provide further evidence of this behavior in this population of neurons.

In agreement with the observed response of cultured MTNs to NTs, we also found that MTNs synthesized the corresponding functional high-affinity receptors TrkB and TrkC, but not TrkA, as evidenced by the ligand-induced autophosphorylation of these receptors (Fig. 4) and by the activation of intracellular signaling pathways involved in neuronal survival and differentiation such as the ERK (Fig. 6). Here we report an excellent correlation between the temporal pattern of trk mRNA expression (Fig. 3), the de novo synthesis of Trk protein (Fig. 5), and the development by cultured MTNs of a survival response to NTs (Fig. 1). This coincidence strengthened the hypothesis that, in the initial phases 
of the culture, chicken MTNs are not able to respond to NTs because they do not express the relevant high-affinity receptors. Expression of $\operatorname{trk} A, \operatorname{trk} B$, and $\operatorname{trk} C$ mRNA is not detected in chicken MTNs at E6, whereas $\operatorname{trkB}$ and $\operatorname{trk} C$ expression is readily detected from E8 by in situ hybridization analysis (J. Comella, unpublished results), and these results are in agreement with those reported by McKay et al. (1996) for $\operatorname{trkB}$. In contrast, in embryonic rat MTNs, mRNA for both $\operatorname{trk} B$ and $\operatorname{trk} C$ but not $\operatorname{trk} A$ (Henderson et al., 1993; Ip et al., 1993) have been detected as early as E15. Consistently, the in vitro survival effects of BDNF, NT3, and NT4/5 on rodent MTNs become evident when MTNs were purified from E15 embryos (Henderson et al., 1993; Hughes et al., 1993b).

NTs belong to the group of molecules that are likely to be present in MEX. It has been shown in rodents that muscle tissue expresses mRNA for NT3 and, at lower levels, for BDNF during physiological MTN death as well as in adulthood (Schecterson and Bothwell, 1992; Henderson et al., 1993). Nevertheless, in the present work we present data suggesting that NTs are probably not responsible for the neurotrophic actions of MEX. First, MTNs purified from E5.5 chick embryos began to respond to stimulation with BDNF, NT3, or NT4/5 only after they had been maintained in culture for 48-72 hr (Figs. 1, 2), whereas they respond to MEX from the beginning of the culture period (E5.5). Second, in cultured MTNs maintained in the presence of MEX it was not possible to detect tyrosine-phosphorylated, i.e., activated, TrkB or TrkC receptors at any time (Fig. $4 B$ ). Moreover, it has been demonstrated that unlike MEX, NTs were not able to rescue MTNs prompted to die by eliminating their target of innervation (McKay et al., 1996). Therefore, MEX is able to induce MTN survival through other neurotrophic agents contained in it.

In the last few years, many neurotrophic agents have been shown to act on MTNs in vitro or when artificially supplied in vivo. Yet, the physiological relevance of most of these agents for MTN development remains unclear. That is the case of the interleukin-6 family of cytokines, including CNTF (Arakawa et al., 1990; Oppenheim, 1991; Sagot et al., 1995), LIF (Martinou et al., 1992), cardiotrophin-1 (Pennica et al., 1995), choline acetyltransferase development factor (McManaman et al., 1990), insulin-like growth factors (Arakawa et al., 1990; Neff et al., 1993), fibroblast growth factors (Arakawa et al., 1990; Hughes et al., 1993a; Gouin et al., 1996), factors from the TGF family, including GDNF (Henderson et al., 1994; Oppenheim et al., 1995; Gouin et al., 1996; Sagot et al., 1996), and very recently, hepatocyte growth factor (Ebens et al., 1996; Sagot et al., 1996). Given the plethora of neurotrophic agents that are able to induce survival responses in MTNs, it is interesting to ask what are the relevant trophic factors for these neurons. The more direct experiments aimed at answering these questions are those in which the neurotrophic factors or their corresponding receptors were deleted in knock-out mice. For the family of NTs and their Trk receptors, these experiments have been inconclusive. Thus, animals that do not express functional BDNF, NT3, or NT4/5 do not show any difference in MTN numbers when compared with wildtype animals (Ernfors et al., 1994a,b; Jones et al., 1994; Conover et al., 1995; Liu et al., 1995). Contrary to what was reported (Klein et al., 1993, 1994), the reevaluation of the phenotype of the $\operatorname{trk} B(-/-), \operatorname{trk} C(-/-)$, or double-null mutant mice has demonstrated that those animals do not show significant differences in the number of MTNs when compared with their corresponding wild-type littermates (Silos-Santiago et al., 1998). Analysis of mice disrupted for the cntfr gene appears to have defined a neurotrophic factor receptor system essential for normal MTN development in vivo because these animals lose $\sim 40 \%$ of their MTN (Dechiara et al., 1995). Similar results have been reported in the $\operatorname{lifr}(-/-)(40 \%$ loss) (Li et al., 1995) and $g d n f(-/-)$ (20-30\% loss) (Moore et al., 1996; Sanchez et al., 1996). Yet, the fact that substantial numbers of MTNs remain in newborn mice lacking $c n t f r$, lifr, or gdnf suggests that MTNs may also depend on additional classes of neurotrophic factors or that there exist subpopulations of MTNs that depend on different neurotrophic factors. One could also imagine a scenario in which distinct MTN subpopulations display different or overlapping neurotrophic requirements in vivo, similar to what has been defined for some sensory neurons (Snider, 1994; Conover et al., 1995). Finally, an alternative explanation would be that trophic requirements of MTNs do not remain the same during embryonic development. This hypothesis is reinforced by the findings herein reported and others described in the literature (McKay et al., 1996).

\section{REFERENCES}

Arakawa Y, Sendtner M, Thoenen H (1990) Survival effect of ciliary neurotrophic factor (CNTF) on chick embryonic motoneurons in culture-comparison with other neurotrophic factors and cytokines. J Neurosci 10:3507-3515.

Averbuch-Heller L, Pruginin M, Kahane N, Tsoulfas P, Parada L, Rosenthal A, Kalcheim C (1994) Neurotrophin-3 stimulates the differentiation of motoneurons from avian neural tube progenitor cells. Proc Natl Acad Sci USA 91:3247-3251.

Barbacid M (1995) Neurotrophic factors and their receptors. Curr Opin Cell Biol 7:148-155.

Barde YA, Edgar D, Thoenen H (1982) Purification of a new neurotrophic factor from mammalian brain. EMBO J 1:549-553.

Berkemeier LR, Winslow JW, Kaplan DR, Nikolics K, Goeddel DV, Rosenthal A (1991) Neurotrophin-5: a novel neurotrophic factor that activates trk and trkB. Neuron 7:857-866.

Bloch-Gallego E, Huchet M, Elmhamdi H, Xie F, Tanaka H, Henderson CE (1991) Survival in vitro of motoneurons identified or purified by novel antibody-based methods is selectively enhanced by musclederived factors. Development 111:221-232.

Boulton TG, Nye SH, Robbins DJ, Ip NY, Radziejewska E, Morgenbesser SD, Depino RA, Panayotos N, Cobb MH, Yancopoulos GD (1991) ERKs: a family of protein-serine/threonine kinases that are activated and tyrosine phosphorylated in response to insulin and NGF. Cell 65:663-675.

Chao MV, Hempstead BL (1995) p75 and trk: a two-receptor system. Trends Neurosci 18:321-326.

Chomczynski P, Sacchi N (1987) Single-step method of RNA isolation by acid guanidinium thiocyanate-phenol-chloroform extraction. Anal Biochem 162:156-159.

Cleveland DW, Kirschner MW, Cowan NJ (1978) Isolation of separate mRNAs for alpha- and beta-tubulin and characterization of the corresponding in vitro products. Cell 15:1021-1031.

Comella JX, Sanz-Rodríguez C, Aldea M, Esquerda JE (1994) Skeletal muscle-derived trophic factors prevent motoneurons from entering an active cell death program in vitro. J Neurosci 14:2674-2686.

Conover JC, Erickson JT, Katz DM, Bianchi LM, Poueymirou WT, Mcclain J, Pan L, Helgren M, Ip NY, Boland P, Friedman B, Wiegand S, Vejsada R, Kato AC, Dechiara TM, Yancopoulos GD (1995) Neuronal deficits, not involving motor neurons, in mice lacking BDNF and/or NT4. Nature 375:235-238.

Davies AM (1994a) The role of neurotrophins in the developing nervous system. J Neurobiol 25:1334-1348.

Davies AM (1994b) Switching neurotrophin dependence. Curr Biol 4:273-276.

Davies AM (1996) The neurotrophic hypothesis: where does it stand? Philos Trans R Soc Lond B Biol Sci 351:389-394.

Davies AM, Horton A, Burton LE, Schmelzer C, Vandlen R, Rosenthal A (1993) Neurotrophin-4/5 is a mammalian-specific survival factor for distinct populations of sensory neurons. J Neurosci 13:4961-4967.

Dechant G, Biffo S, Okazawa H, Kolbeck K, Pottgiesser J, Barde YA (1993) Expression and binding characteristics of the BDNF receptor chicken TrkB. Development 119:545-558. 
Dechiara TM, Vejsada R, Poueymirou WT, Acheson A, Suri C, Conover JC, Friedman B, Mcclain J, Pan L, Stahl N, Ip NY, Kato A, Yancopoulos GD (1995) Mice lacking the CNTF receptor, unlike mice lacking CNTF, exhibit profound motor neuron deficits at birth. Cell 83:313-322.

Dohrmann U, Edgar D, Sendtner M, Thoenen H (1986) Muscle-derived factors that support survival and promote fiber outgrowth from embryonic chick spinal motor neurons in culture. Dev Biol 118:209-221.

Ebens A, Brose K, Leonardo ED, Hanson MG, Bladt F, Birchmeier C, Barres BA, Tessierlavigne M (1996) Hepatocyte growth factor/scatter factor is an axonal chemoattractant and a neurotrophic factor for spinal motor neurons. Neuron 17:1157-1172.

Ernfors P, Lee KP, Jaenisch R (1994a) Mice lacking brain-derived neurotrophic factor develop with sensory deficits. Nature 368:147-150.

Ernfors P, Lee KP, Kucera J, Jaenisch R (1994b) Lack of neurotrophin-3 leads to deficiencies in the peripheral nervous system and loss of limb proprioceptive afferents. Cell 77:503-512.

Funakoshi H, Belluardo N, Arenas E, Yamamoto Y, Casabona A, Persson H, Ibanez CF (1995) Muscle-derived neurotrophin-4 as an activity-dependent trophic signal for adult motor neurons. Science 268:1495-1499.

Garner AS, Large TH (1994) Isoforms of the avian TrkC receptor: a novel tyrosine kinase insertion dissociates transformation and process outgrowth from survival. Neuron 13:457-472.

Gouin A, Bloch-Gallego E, Tanaka H, Henderson CE (1996) Transforming growth factor-beta3, glial cell line-derived neurotrophic factor and fibroblast growth factor- 2 act in different manners to promote motoneuron survival in vitro. J Neurosci Res 43:454-464.

Hamburger V (1975) Cell death in the development of the lateral motor column of the chick embryo. J Comp Neurol 160:535-546.

Henderson CE (1996) Role of neurotrophic factors in neuronal development. Curr Opin Neurobiol 6:64-70.

Henderson CE, Camu W, Mettling C, Gouin A, Poulsen K, Karihaloo M, Rullamas J, Evans T, McMahon SB, Armanini MP, Berkemeier L, Phillips HS, Rosenthal A (1993) Neurotrophins promote motor neuron survival and are present in embryonic limb bud. Nature 363:266-270.

Henderson CE, Phillips HS, Pollock RA, Davies AM, Lemeulle C, Armanini M, Simpson LC, Moffet B, Vandlen RA, Koliatsos VE, Rosenthal A (1994) GDNF: a potent survival factor for motoneurons present in peripheral nerve and muscle. Science 266:1062-1064.

Hughes RA, Sendtner M, Goldfarb M, Lindholm D, Thoenen H (1993a) Evidence that fibroblast growth factor-5 is a major muscle-derived survival factor for cultured spinal motoneurons. Neuron 10:369-377.

Hughes RA, Sendtner M, Thoenen H (1993b) Members of several gene families influence survival of rat motoneurons in vitro and in vivo. J Neurosci Res 36:663-671.

Ip NY, Stitt TN, Tapley P, Klein R, Glass DJ, Fandl J, Greene LA, Barbacid M, Yancopoulos GD (1993) Similarities and differences in the way neurotrophins interact with the trk receptors in neuronal and nonneuronal cells. Neuron 10:137-149.

Jones KR, Fariñas I, Backus C, Reichardt LF (1994) Targeted disruption of the BDNF gene perturbs brain and sensory neuron development but not motor neuron development. Cell 76:989-999.

Klein R, Smeyne RJ, Wurst W, Long LK, Auerbach BA, Joyner AL, Barbacid M (1993) Targeted disruption of the trkB neurotrophin receptor gene results in nervous system lesions and neonatal death. Cell 75:113-122.

Klein R, Silos-Santiago I, Smeyne RJ, Lira SA, Brambilla R, Bryant S, Zhang L, Snider WD, Barbacid M (1994) Disruption of the neurotrophin-3 receptor gene TrkC eliminates Ia muscle afferents and results in abnormal movements. Nature 368:249-251.

Koliatsos VE, Clatterbuck RE, Winslow JW, Cayouette MH, Price DL (1993) Evidence that brain-derived neurotrophic factor is a trophic factor for motor neurons in vivo. Neuron 10:359-367.

Lewin GR, Barde YA (1996) Physiology of neurotrophins. Annu Rev Neurosci 19:289-317.

Li P, Allen H, Banerjee S, Franklin S, Herzog L, Johnston C, Mcdowell J, Paskind M, Rodman L, Salfeld J, Towne E, Tracey D, Wardwell S, Wei F, Wong W, Kamen R, Seshadri T (1995) Mice deficient in IL-1b-converting enzyme are defective in production of mature IL-1b and resistant to endotoxic shock. Cell 80:401-411.

Liu X, Ernfors P, Wu H, Jaenisch R (1995) Sensory but not motor neuron deficits in mice lacking NT4 and BDNF. Nature 375:238-241. Maisonpierre PC, Belluscio L, Friedman B, Alderson RF, Wiegand SJ,
Furth ME, Lindsay RM, Yancopoulos GD (1990) NT-3, BDNF, and NGF in the developing rat nervous system: parallel as well as reciprocal patterns of expression. Neuron 5:501-509.

Martinou JC, Martinou I, Kato AC (1992) Cholinergic differentiation factor $(\mathrm{CDF} / \mathrm{LIF})$ promotes survival of isolated rat embryonic motoneurons in vitro. Neuron 8:737-744.

Martín-Zanca D, Oskam R, Mitra G, Copeland T, Barbacid M (1989) Molecular and biochemical characterization of the human trk protooncogene. Mol Cell Biol 9:24-33.

McKay SE, Garner A, Calderó J, Tucker RP, Large T, Oppenheim RW (1996) The expression of trkB and p75 and the role of BDNF in the developing neuromuscular system of the chick embryo. Development 122:715-724.

McManaman JL, Oppenheim RW, Prevette D, Marchetti D (1990) Rescue of motoneurons from cell death by a purified skeletal muscle polypeptide: effects of the ChAT development factor, CDF. Neuron 4:891-898.

Mettling C, Gouin A, Robinson M, Elmhamdi H, Camu W, Gallego EB, Buisson B, Tanaka H, Davies AM, Henderson CE (1995) Survival of newly postmitotic motoneurons is transiently independent of exogenous trophic support. J Neurosci 15:3128-3137.

Moore MW, Klein RD, Fariñas I, Sauer H, Armanini M, Phillips H, Reichardt LF, Ryan AM, Carver-Moore K, Rosenthal A (1996) Renal and neuronal abnormalities in mice lacking GDNF. Nature 382:76-79.

Neff NT, Prevette D, Houenou LJ, Lewis ME, Glicksman MA, Yin QW, Oppenheim RW (1993) Insulin-like growth factors: putative musclederived trophic agents that promote motoneuron survival. J Neurobiol 24:1578-1588.

Oppenheim RW (1991) Cell death during development of the nervous system. Annu Rev Neurosci 14:453-501.

Oppenheim RW (1996) Neurotrophic survival molecules for motoneurons: an embarrassment of riches. Neuron 17:195-197.

Oppenheim RW, Quinwei Y, Prevette D, Yan Q (1992) Brain-derived neurotrophic factor rescues developing avian motoneurons from cell death. Nature 360:755-757.

Oppenheim RW, Prevette D, Haverkamp LJ, Houenou L, Yin QW, McManaman J (1993) Biological studies of a putative avian musclederived neurotrophic factor that prevents naturally occurring motoneuron death in vivo. J Neurobiol 24:1065-1079.

Oppenheim RW, Houenou LJ, Johnson JE, Lin LFH, Li LX, Lo AC, Newsome AL, Prevette DM, Wang SW (1995) Developing motor neurons rescued from programmed and axotomy-induced cell death by GDNF. Nature 373:344-346.

Pennica D, King KL, Shaw KJ, Luis E, Rullamas J, Luoh S, Darbonne WC, Knutzon DS, Yen R, Chien KR, Baker JB, Wood WI (1995) Expression cloning of cardiotrophin 1, a cytokine that induces cardiac myocyte hypertrophy. Proc Natl Acad Sci USA 92:1142-1146.

Sagot Y, Tan SA, Baetge E, Schmalbruch H, Kato AC, Aebischer P (1995) Polymer encapsulated cell lines genetically engineered to release ciliary neurotrophic factor can slow down progressive motor neuronopathy in the mouse. Eur J Neurosci 7:1313-1322.

Sagot Y, Tan SA, Hammang JP, Aebischer P, Kato AC (1996) GDNF slows loss of motoneurons but not axonal degeneration or premature death of PMN/PMN mice. J Neurosci 16:2335-2341.

Sanchez MP, Silos-Santiago I, Frisen J, He B, Lira SA, Barbacid M (1996) Renal agenesis and absence of enteric neurons in mice lacking GDNF. Nature 392:70-73.

Schecterson LC, Bothwell M (1992) Novel roles for neurotrophins are suggested by BDNF and NT-3 messenger RNA expression in developing neurons. Neuron 9:449-463.

Silos-Santiago I, Fagan AM, Garber M, Fritzch B, Barbacid M (1997) Severe sensory deficit but normal CNS development in newborn mice lacking TrkB and TrkC tyrosine protein kinase receptors. Eur J Neurosci 9:2045-2056.

Snider WD (1994) Functions of the neurotrophins during nervous system development: what the knockouts are teaching us. Cell 77:627-638.

Thoenen H (1991) The changing scene of neurotrophic factors. Trends Neurosci 14:165-170.

Vejsada R, Sagot Y, Kato AC (1995) Quantitative comparison of the transient rescue effects of neurotrophic factors on axotomized motoneurons in vivo. Eur J Neurosci 7:108-115.

Yan Q, Elliott JL, Matheson C, Sun J, Zhang L, Mu X, Rex KL, Snider WD (1993) Influences of neurotrophins on mammalian motoneurons in vivo. J Neurobiol 24:1555-1577. 